\title{
Pengaruh Pembelajaran Berbasis Permainan Online Terhadap Kecerdasan Fisik Motorik Anak Usia Dini
}

\author{
Andri Arif Kustiawan \\ Universitas Sebelas Maret Surakarta \\ andrigww3m@gmail.com
}

Shinta Aulia Enggarwati

PIAUD, Fakultas Ilmu Tarbiyah dan Keguruan, UIN Walisongo Semarang shinta1803106044@student.walisongo.ac.id

\begin{abstract}
Technology is developing very rapidly so that it can simplify human work, both science, information, games, buying and selling, and so on on the internet. Apart from having an impact on the fast and easy access to information, it also has an impact on health, social, intelligence, psychological, financial and other aspects. It is excessive if it is overused to make it addictive. Such as addiction to online games, TikTok, and youtube which results in dependence and underestimates health and time. This research uses literacy studies. The purpose of this study is to present findings of the impact of gadget use on children. The results show that technological advances have both positive and negative impacts. There are various kinds of game applications that are easily accessed by children, both game content and those that can stimulate children's development, such as creativity, memory, physical motor, cognitive and so on. So it is necessary to take preventive steps so that technological developments can also reduce the negative impact on children's development.
\end{abstract}

Keywords : games; online; intelligence; physical; motoric; early childhood; 


\section{ABSTRAK}

Teknologi berkembang sangat pesat sehingga dapat mempermudah pekerjaan manusia, baik ilmu pengetahuan, informasi, game, jual beli dan lainnya terdapat pada internet. Selain berdampak pada cepat dan mudahnya akses informasi juga berdampak pada aspek kesehatan, sosial, kecerdasan, psikologis, keuangan, dan lainya. Terlebih jika berlebihan dalam penggunaannya sampai menjadikan candu. Seperti kecanduan game online, TikTok, maupun youtube yang berakibat ketergantungan dan menyepelekan kesehatan dan waktu.Penelitian ini menggunakan studi literasi. Tujuan penelitian ini menunjukkan temuan tentang dampak penggunaan gadget untuk pada anak-anak. Hasil penelitian menunjukkan kemajuan teknologi memiliki dampak positif dan negatif. Terdapat berbagai macam aplikasi game yang mudah diakses anak baik conten game maupun yang dapat menstimulus perkembangan anak,seperti kreativitas, daya ingat, fisik motorik, kognitif dan sebagainya. Maka perlu langkah preventif sehingga perkembangan teknologi juga dapat menekan dampak negatifnya bagi perkembangan anak.

Kata kunci : permainan; online; kecerdasan, fisik; motorik; anak usia dini; 


\section{PENDAHULUAN}

Banyak tugas tersedia untuk mengukur fungsi eksekutif kemampuan dan keterampilan anak yang berupa memori kerja atau daya ingat, hambatan dan fleksibilitas tubuh pada anak-anak. Mereka memiliki perbedaan mengenai cara penyajian dan perlakuannya. Beberapa berisi stimulus yang ramah anak, umpan balik, atau permainan yang cenderung meningkatkan motivasi dan minat untuk melakukan tugas pada anak(Johann \& Karbach, 2018). Perkembangan Teknologi zaman sekarang sudah sangat canggih dan maju, teknologi akan berjalan sesuai kemajuan ilmu pengetahuan. Teknologi diciptakan guna memberikan kemudahan dan manfaat bagi manusia. masyarakat saat ini sudah banyak yang menggunakan teknologi dan sangat menikmatinya. Teknologi sangat penting di kenalkan kepada anak sejak dini, agar anak tidak ketinggalan zaman yang modernisasi pada saat ini. Akan tetapi kita harus perlu pengawasan sampai anak mengetahui baik buruknya teknologi. Dengan adanya teknologi sangat membantu pada dunia pendidikan. Karena didalam teknologi terdapat internet. dan di dalam internet terdapat banyak ilmu yang mempermudah anak-anak mencari jawaban ketika mendapatkan soal dari guru. Dengan demikian teknologi memberikan manfaat positif bagi manusia tetapi di sisi lain juga terdapat sisi negatif bagi manusia maupun anak usia dini(R Elindawati, 2020).

Dampak negatif teknologi dalam kehidupan masyarakat terutama yaitu sosial dan budaya mereka, pola perilaku keseharian anak akan menurun sehingga anak akan sering menggunakan gadget dari pada kegiatan yang lainnya. Teknologi juga sangat membantu masyarakat salah satunya dapat berkomunikasi dengan jarak jauh dan dapat melihat wajah orang yang diajak berbicara. Kemajuan teknologi telah mempengaruhi anak-anak zaman sekarang sehingga mereka lebih mementingkan gadget dari pada perintah orang tuanya. Ketika anak kecanduan gadget ia akan sulit untuk mengerjakan kegiatan lainnya. Terkadang anak kalau di suruh makan, mandi atau yang lainnya dan mereka masih bermain gadget mereka akan mengabaikan perintah itu dan mementingkan gadget nya. Saat ini terdapat aplikasi yang sedang viral contohnya TikTok, TikTok merupakan aplikasi yang berisi unggahan video lucu dan unik. Aplikasi ini sangat bermanfaat bagi perkembangan kecerdasan anak. Anak jika di tontonkan videovideo ia akan menangkap apa yang barusan ia lihat. Tetapi anak harus kita awasi akan video yang ingin di tonton anak. Anak harus 
diperlihatkan video-video yang bermanfaat seperti misalnya video mengenai lagu-lagu anak maupun sholawat agar anak tumbuh dengan kepribadian yang baik. Anak akan cenderung mengikuti perilaku seperti apa yang anak tonton sehingga diharapkan anak mengalami perubahan perilaku yang baik. Perwujudan perilaku belajar biasanya terlihat dari perubahan-perubahan kebiasaan, keterampilan, pengamatan, sikap dan kemampuan yang biasanya disebut sebagai hasil belajar(Ariantoro, 2016).

Kehadiran internet dalam kehidupan manusia mampu menembus batas dimensi kehidupan mereka/pengguna, tentang ruang dan waktu pengguna, termasuk yang dapat diakses oleh siapapun, kapanpun, dan dimanapun. Selain media sosial juga terdapat permainan online ataupun offline yang tersedia dalam gadget yang akan mempengaruhi perkembangan dan pertumbuhan anak(Junida, 2019). Gadget sebagai media informasi bagi manusia dan anak akan sangat membantu mereka dalam melakukan berbagai aktivitas seharihari. Gadget juga memiliki peran penting mengarahkan dan mengawasi perilaku anak sehari-hari. Anak-anak belum dapat membedakan pengaruh positif dan negatif dari permainan online tersebut, untuk itu orang tua yang harus mengarahkan dan mengawasi aktivitas bermain online anak agar berkembangan sesuai dengan tahapan perkembangannya. Permainan atau game online tidak selalu memiliki pengaruh yang buruk terhadap anak, namun juga memiliki pengaruh yang baik terhadap anak. Jika permainan online dilakukan secara terus menerus oleh anak maka akan mengakibatkan anak menjadi kurang peka terhadap lingkungan sosial dan anak menjadi malas untuk bergerak(Rohman, 2018).

Bermain gadget tidak hanya menimbulkan dampak negatif bagi anak, karena juga ada dampak positif, diantaranya dalam pola pikir anak yaitu mampu membantu anak dalam mengatur kecepatan bermainnya, mengolah strategi dalam permainan, dan membantu meningkatkan kemampuan otak kanan anak selama dalam pengawasan yang baik(Chusna, 2017). Pola pikir anak memiliki pengaruh terhadap kecerdasan anak. Anak memiliki kecerdasan yang berbeda-beda. Namun sayangnya banyak orang tua tidak memahami hal tersebut. Orang tua cenderung menginginkan bahwa anak mereka lebih unggul dari anak lain pada bidang-bidang yang diajarkan pada lembaga sekolah formal seperti misalnya kecerdasan berhitung pada pelajaran matematika, kecerdasan berbahasa atau linguistik dan 
kecerdasan interpersonal yaitu kecerdasan bersosial di masyarakat. Kecerdasan bergerak atau kinestetik seringkali kurang diperhatikan oleh orang tua. Padahal, tipe kecerdasan tersebut sangat penting untuk menunjang kehidupan anak sehari-hari. Orang-orang yang berprofesi sebagai atlet merupakan salah satu contoh manusia yang memiliki kecerdasan bergerak. Oleh sebab itu orang tua diharapkan memahami pentingnya membuat anak selalu bergerak dengan tujuan apapun. Namun, hal tersebut menjadi sulit dilaksanakan pada zaman ini karena pengaruh globalisasi dari game atau permainan online.

\section{KAJIAN PUSTAKA}

\section{Pengertian Anak Usia Dini}

Anak usia dini adalah anak usia 0-6 tahun. Pada masa ini anak merupakan masa golden age. Masa ini merupakan masa berkembangnya semua potensi anak. Pada masa ini potensi anak akan berkembang dengan cepat. Masa anak usia dini yaitu masa bermain, masa berkembang, masa ekplorasi dan lainnya. Setiap anak dilahirkan dengan keadaan bersih suci. Mereka belum mengetahui apa-apa. Maka dari itu kita sebagai orang tua untuk mendidik anak agar menjadi pribadi yang lebih baik. Anak memiliki perkembangan pada aspek, sosial-emosionalnya, kognitifnya, kreativitasnya, bahasanya dan lain sebagainya. Pada perkembangan anak, anak memiliki kecerdasan yang berbeda-beda. Anak membutuhkan makanan yang sehat dan gizi yang penuh agar tumbuh kembang anak akan stabil. Masa kanak-kanak belum mampu mengembangkan potensinya. Pada masa ini anak lebih senang bermain, dan ingin menang sendiri. Anak usia dini lebih suka berimajinasi yang kreatif akan bahasanya. Pada usia 0-1 perkembangan anak lebih ke fisik motoriknya seperti tengkurap, berguling, duduk, merangkak, berdiri, berjalan. Dan panca inderanya pun mulai berkembang seperti meraba, melihat, mengecap, mendengar, dan sering memasukan benda ke mulut. komunikasi socsial anak seperti anak ketika di ajak berbicara anak akan merespon. Pada usia 2-3 tahun akan mengalami pertumbuhan pada fisiknya seperti anak aktif dalam mengeksplorasi benda, anak akan lebih sering berceloteh karena ia sedang mencoba belajar berkomunikasi. Pada usia 3-6 tahun anak akan memasuki Taman Kanak-Kanak. Pada masa ini anak mengalami perkembangan pada fisiknya seperti sangat aktif dalam setiap kegiatan, pekembangan berbicaranya lebih meningkat, anak akan lebih sering bertanya tentang benda ataupun yang lain yang 
berada di dekatnya. Daya ingat Anak usia dini sangat tajam sehingga orang tua diharapkan mampu memberikan stimulasi yang tepat agar anak tumbuh dan berkembang dengan baik.

2. Perkembangan Teknologi dan pengaruhnya terhadap anak

Pada saat ini, kita hidup dizaman modernisasi. Modernisasi mencakup banyak bidang yaitu bidang teknologi dan ilmu pengetahuan. Teknologi sudah ada sejak dulu, namun belum secanggih zaman sekarang. Teknologi dizaman sekarang ini sangat canggih dan berkembang sangat pesat. Teknologi merupakan sarana atau metode yang menyediakan sesuatu yang diperlukan oleh manusia sebagai kenyamanan dan kelangsungan hidup. Teknologi akan membuat perubahan, kemajuan, dan peningkatan. Modernisasi merupakan transformasi dari keadaan masyarakat yang sederhana kearah yang lebih baik atau masyarakat yang lebih maju. Perubahan tersebut pasti akan terjadi seiring berjalannya zaman dengan perkembangan teknologi. Pada zaman modernisasi ini setiap orang sangat bergantung pada teknologi. Hingga saat ini teknologi menjadi kebutuhan dasar bagi setiap orang. Dari orang muda hingga orang tua, para ahli hingga orang awam pun menggunakan teknologi dalam berbagai aspek kehidupannya. Perkembangan teknologi saat ini semakin maju, dulu handphone yang hanya bisa untuk telephon dan sms, pada saat ini handphone juga dapat mencari berbagai informasi dan lainnya. Karena komunikasi itu sangat penting bagi kelangsungan hidup manusia.

Internet merupakan sebuah teknologi yang didalamnya terdapat banyak informasi berupa tulisan, gambar dan video. Adapun macammacam media di internet contohnya seperti facebook, instagram, whatshap, game online, youtube, TikTok, dan sebagainya. Mendorong kreativitas anak, anak jadi lebih kreatif akan imajinasinya, dan mengenalkan macam-macam musik yang ada di TikTok, melatih kepercayaan diri didepan kamera ataupun orang lain. (Susilowati, 2018). Teknologi pada saat ini sudah sangat canggih, apapun menggunakan internet, mau makan bisa pake grab, mau pergi bisa pake grab, mau apa aja bisa menggunakan internet. dalam internet juga terdapat media untuk jual beli barang, baju, make up, sepatu, tas, hingga sembako juga dapat dibeli lewat online. Internet juga bisa menjadi dampak negatif bagi semua orang, dan pada saat ini banyak sekali orang yang terlalu over menggunakan handphone sehingga semua orang menjadi ketergantungan terhadap teknologi sehingga malas untuk berfikir. 
3. Pengertian Kecerdasan Anak

Setiap orang tua pasti ingin memiliki anak yang cerdas. Kecerdasan anak tidak hanya diukur melalui ukuran IQ, Setiap anak memiliki kecerdasan yang majemuk, yaitu kecerdasan intelektual (IQ) dan kecerdasan emosional (EQ)(Suarca, Soetjiningsih, \& Ardjana, 2016). Adapun berbagai macam jenis kecerdasan anak, jenis-jenis kecerdasan yang dicetuskan oleh Howard Gardner. Pada teori multiple intelligences tersebut menjelaskan bahwa pada dasarnya manusia memiliki banyak kecerdasan tidak hanya sebatas IQ maupun EQ saja, namun berbagai kecerdasan tersebut memiliki peran yang sama penting untuk mengantarkan manusia tersebut sukses(Machali, 2014). Pandangan ini membuat seseorang mempunyai persepsi yang berbeda mengenai bakat yang dimiliki setiap orang dan membuka wawasan baru mengenai jenis-jenis kecerdasan. Memang kecerdasan anak itu berbeda-beda, kita tidak tahu anak akan tumbuh dengan kecerdasan yang seperti apa, maka dari itu kita harus mengetahui jenis-jenis kecerdasan yang dikemukakan oleh para ahli. Contohnya dari (Strauss \& Gardner, 2013)ada 4 jenis yang dikemukakan olehnya yaitu :

a. Kecerdasan Visual-Spasial

Kecerdasan visual-spasial ini terletak pada kemampuan berfikir, kemampuan visualisasi yang sangat baik, menerjemah dan memahami pikiran atau imajinasi ke dalam bentuk visual. Anak yang mempunyai Kecerdasan visual-spasial ini mempunyai kemampuan yang lebih dibanding anak-anak lainnya, terutama pada daya ingat dan menerjemahkan isi pikirannya. Dan anak lebih mudah mengingat sebuah gambar, video, dan sebagainya. Ciri yang menonjol dari anak yang mempunyai kecerdasan visual-spasial ini adalah kemampuan menggambar dengan jelas garis dan warna yang sangat baik.

b. Kecerdasan Interpersonal

Kecerdasan interpersonal adalah kemampuan anak untuk mengamati dan mengerti maksud, motivasi, dan perasaan orang lain. Mengerti akan suara dan gerakan tubuh orang lain, maupun peka terhadap ekspresi wajah orang lain, dan mampu memberikan respon secara efektif dalam berkomunikasi. Ketika dipanggil atau diberi candaan dia akan meresponnya ataupun akan tersenyum. Contohnya ketika ada orang atau anak kecil banyak, anak tidak takut tetapi senang ketika melihat orang banyak ataupun anak seusiannya yang ramai. Dengan terbiasanya diajak ke suatu tempat yang melibatkan orang banyak anak akan mengetahui bahwa diluar sana ada orang lain yang 
bisa bersama-sama dengan dirinya. Kemampuan anak dengan pintar berbicara yaitu salah satu ciri kecerdasan interpersonal anak.

c. Kecerdasan Naturalis

Kecerdasan naturalis merupakan kecerdasan yang unik, kapasitas anak untuk mengeksplor lingkungannya, dan mengelompokkan lingkungan fisik disekitarnya, misalnya binatang, tumbuhan dan lainnya. Dan kemampuan anak untuk mencintai sesama makhluk hidup dan lingkungan. Pada kecerdasan ini anak lebih suka dengan alam terbuka, nyaman dan peduli dengan sesuatu yang berhubungan dengan alam. Anak dapat mengenali jenis flora dan fauna, menyayangi berbagai jenis binatang, dan mengerti akan fenomena alam. Kecerdasan naturalis ini anak biasanya lebih diajak berkebun, merawat bunga, berwisata ke suatu pantai, sungai, kebun binatang, atau yang lainnya yang bersangkutan dengan alam.

d. Kecerdasan Linguistik-Verbal

Kecerdasan linguistik-verbal merupakan kecerdasan untuk mengekspresikan diri dengan berbicara dan menulis, ataupun bahasa dan kata-kata. Anak dengan kecerdasan linguistik-verbal ini akan lebih sering berbicara, ataupun mendengarkan cerita. Pada kecerdasan ini orang tua dapat membiasakan dari kecil sudah sering mengajak berbicara ataupun bercerita bahkan sejak dalam kandunganpun ibu membiasakan membaca atau mengajak berbicara dengan janin agar sejak dalam kandungan anak akan tertanam kecerdasan linguistikverbal nya. Adapun cara lain agar kecerdasan linguistik-verbal ini tertanam pada anak, orang tua mengajak anak menonton pertunjukan yang melibatkan peran. Anak yang berbakat pada kecerdasan linguistik-verbal lebih senang bermain dengan bahasa, bermain peran, atau bermain suara (menyanyi). Jika anak yang mempunyai kecerdasan linguistik-verbal anak akan mampu menceritakan atau menuliskan pengalaman kesehariannya, ia akan lebih banyak memiliki kosakata.

Pembelajaran gerak dan lagu adalah salah satu cara yang dilakukan guru dalam menyajikan materi pembelajaran dalam tema dan hal tersebut memudahkan peserta didik dalam mengingat tema dalam pembelajaran(Viana, 2020). Jika anak menyukai permainan online, orang tua harus mengarahkan anak agar juga melakukan gerak yang seirama sesuai dengan lagu yang ada atau orang tua harus mengusahakan agar anak juga ikut bergerak. Setelah itu, orang tua harus memberikan dasar yang kuat kepada anak dengan cara 
bertanyadan melakukan komunikasi kepada anak agar orang tua dapat menjali kedekatan psikologis kepada anak. Memanfaatkan kecerdasan kinestetik anak terhadap kemampuan literasi yang baik, akan mampu membendung pengalihan pengaruh konten-konten negatif teknologi seperti game-game on-line bergenre kekerasan atau situs-situs radikal menuju penciptaan karya-karya nyata(Suhaimi, 2017). Jika orang tua dapat mengarahkan anak dan melakukan komunikasi yang baik dengan anak, maka anak akan dengan senang hati mengizinkn orang tua untuk memasuki kehidupan mereka yaitu mengizinkan orang tua untuk mengakses permainan maupun game online yang sedang anak mainkan. Hal tersebut menjadi kunci utama agar anak dapat memaksimalkan kecerdasan kinesthetiknya atau kecerdasan geraknya sehingga diharapkan anak-anak dapat tumbuh dan berkembangan melebihi potensinya.

\section{METODE PENELITIAN}

Penelitian ini menggunakan jenis penelitian studi kepustakaan (Library Research). Metode pendekatan penelitian ini dapat digunakan sebagai sumber informasi dan data yang tercantum didalam beberapa dokumen seperti buku, majalah, jurnal, koran, dan berbagai sumber informasi lainnya yang berkaitan dengan penelitian ini. Selain itu, metode studi kepustakaan juga merupakan hasil karya ilmiah yang didapatkan dan dikembangkan dari beberapa referensi penelitian sejenis yang sudah ada sebelumnya.

\section{HASIL DAN PEMBAHASAN}

Teknologi memiliki dampak positif dan negatif terutama bagi anak usia dini. Teknologi juga memiliki dampak negatif bagi kebudayaan dan sistem pendidikan di Indonesia. Dampak negatif bagi kebudayaan Indonesia yaitu masuknya budaya asing yang tidak baik untuk anak Indonesia, lupa akan waktu sehingga anak selalu memainkan internet sampai berjam-jam, merosotnya nilai moral, kecanduan akan game online karena game online itu lebih seru di banding game offline di dalam game online terdapat banyak level dan bisa bermain dengan banyak orang, berkurang nya kewajiban belajar pada anak sehingga anak malas untuk belajar karena dianggapnya belajar adalah kegiatan yang membosankan, sehingga mereka lebih memilih untuk bermain gadget dan menonton video, game online atau yang lainnya yang ada di internet, munculnya akun-akun yang tidak 
asli, dan banyaknya penipuan atau hoax-hoax yang di sebar di media sosial, anak juga akan terpengaruh akan video-video yang di unggah di internet, seperti video yang di unggah di youtube, maupun TikTok akan membuat anak menjadi lebih sering bergoyang, karena di dalam TikTok terdapat video berupa music dan gerakannya. Ternyata selain berpengaruh terhadap kehidupan sehari-hari, gadget juga mengganggu kesehatan kita. Maka dari itu setiap anak bermain gadget harus dibatasi dan pengawasan agar tidak terjadinya dampak tersebut(Adhipurna, n.d.2020).

Teknologi sangat membantu bagi masyarakat pada zaman sekarang yaitu lebih mudah ketika ingin berkomunikasi dengan teman atupun keluarga yang jauh dengan cara menelfon ataupun yang lain, kemudahan dalam berbelanja hanya dengan cara buka aplikasi jual beli online, jika ingin bepergian jauh menggunakan kereta, pesawat ataupun yang lain bisa menggunakan gadget, dan lebih mudah menerima informasi dengan cepat, ketika kita ingin mencari lowongan pekerjaan juga dapat menggunakan gadget kita dapat mencari lowongan tersebut di internet. Seperti saat ini, di kalangan anak-anak sampai remaja sudah menggunakan media teknologi. Terutama yang paling popular pada saat ini yaitu TikTok. Apa itu TikTok? TikTok merupakan permainan online yang didalamnya aplikasi pembuat video dengan fitur-fitur yang sangat keren, dan unik. Sehingga orang-orang yang menggunakannya bisa mudah melihat video yang sudah ada diaplikasi tersebut. Mengapa banyak orang menggunakan TikTok? Karena TikTok merupakan aplikasi yang dapat menghilangkan kebosanan ataupun stress pada diri. Tik-tok sering di gunakan anakanak, mereka membuat video beserta gerakannya dan di unggah agar mereka dapat di lihat oleh orang lain yang menggunakan media sosial.

TikTok juga membawa dampak negatif ketika video yang ditontonnya tidak sesuai dengan usia anak. Oleh karena itu jika anak cenderung lebih sering menonton TikTok sebaiknya orang tua mengganti tontonannya dengan video yang berkaitan dengan agama atau permainan anak-anak(Safira \& Ifadah, 2020). Dampak Penggunaan TikTok Pada Anak-Anak telah membuat resah orang tua. Berdasarkan pengamatan melalui lingkungan keluarga, terdapat sanak saudara berusia dua tahun yang terlihat selalu memegang HP dan memainkannya sehingga gerak fisik motoriknya menjadi terhambat. Contoh lain ketika ditontonkan TikTok sholawat, atau lagu anak-anak, kemudian anak hafal lagu dan gerakan pada video tersebut, anak 
berkembang kecerdasan fisik-motoriknya, TikTok juga mendorong kreativitas anak dan mengikuti gaya ketika kita berdoa, anak akan mengangkat kedua tangan ketika mendengar atau melihat lagu dan video tersebut. Adapun lagu anak-anak yang diikutinya dengan wajah gembira. Karena anak usia dini rasa ingin tahunya sangat besar, ketika mereka mendengar atau melihat sesuatu yang menarik anak akan penasaran akan hal tersebut. Ketika anak bermain TikTok akan membuat penonton atau orang tua akan merasa senang, lucu ketika melihat anaknya pintar akan menirukan gerakan tersebut. Perkembangan TikTok memberikan perkembangan pada pancaindra dan daya ingat. Karena setiap anak melihat suatu video yang ada di TikTok anak akan mengamati bagaimana gerakannya, dan mendengarkan musiknya sehingga anak dapat mengikuti video tersebut.

Dampak negatif TikTok adalah anak-anak dijaman sekarang suka bergoyang, dan membuat video-video kurang wajar dikalangan anak. Anak juga lebih sering mengutamakan gadgetnya di bandingkan dengan keluarganya ini adalah dampak psikologis anak jika memainkan gadget berlebihan. banyak sekali dimedia sosial maupun televisi, anak-anak remaja viral karena mereka membuat video yang lucu, maupun yang tidak wajar diTikTok, sehingga mereka terkenal akan video yang mereka aploud. Maka dari itu orang harus benarbenar mengawasi anak ketika mereka menggunakan gadget ataupun bermain TikTok. Selain aplikasi TikTok juga terdapat aplikasi lain yaitu youtube. Youtube sudah ada sebelum TikTok ada. Dan aplikasi youtube juga tidak kalah kerennya dengan aplikasi TikTok. Youtube adalah sebuah aplikasi yang isinya sebuah informasi yang dijadikan videovideo. Didalam aplikasi youtube banyak sekali orang mengunggah video tentang informasi, tutorial, maupun sekedar bercerita. Apabila ingin mencari sesuatu diyoutube kemungkinan besar ada semua di youtube, contohnya tutorial masak, make up, belajar nari, sholawatan, atau belajar tentang agama, dan masih banyak lagi video yang ada diyoutube. Video yang diunggah di youtube membuat orang-orang menjadi lebih mudah ketika ingin belajar dengan mudah, ataupun ingin mendengarkan musik pun bisa menggunakan youtube. Youtube juga dapat mencari informasi-informasi terkini dengan sangat mudah, ingin tahu informasi di dalam negeri maupun luar negeri itu sangat mudah dengan menggunakan youtube. Dengan unggahan-unggahan video tersebut memberikan keuntungan bagi para penikmat youtube yang 
sedang mencari informasi ataupun mencari ilmu. Youtube bisa membuat orang-orang menjadi terkenal dan mendapatkan uang. Sebelum adanya TikTok, youtube menjadi terpopular hingga sekarang pun juga masih popular.

Orang yang suka mengunggah video di youtube disebut youtuber, youtuber adalah orang yang sering mengunggah video yang mereka buat, video lucu, sedih, bermanfaat, ataupun yang lainnya. Tetapi rata-rata orang yang mengunggah video di youtube adalah video vlog. Vlog yaitu orang didepan kamera dan berbicara apa yang di depannya atau spontan. Pada zaman modern, perkembangan media sosial sangat mudah diakses oleh anak-anak, perkembangan ini tentunya mempengaruhi perkembangan teknologi dalam bidang informasi. Anak-anak zaman sekarang sudah banyak yang menonton youtube dan banyak sekali hiburan dari anak muda sampai tua pun menggunakannya.

Terdapat berbagai reaksi pada anak setelah menonton video di youtube tersebut, diantaranya adalah anak langsung menirukan kecapan bibir saja tidak bersuara, tetapi merupakan perkembangan kognitif bagi anak, dari yang sebelumnya belum tahu lagu sampai bisa menirukan. Tetapi ada satu catatan bagi orang tua jika menontonkan youtube kepada anak, harus dengan pengawasan yang lebih. Adanya youtube di media sosial mengajarkan anak agar pintar atau lancar dalam berbicara, karena di dalam aplikasi youtube terdapat banyak sekali vlog ataupun video. jika anak memanfaatkan youtube dengan baik, youtube sangat membantu anak jika anak kesulitan dalam belajar dan menambah wawasan bagi anak. Contoh nya jika anak sulit mengerjakan tugas dan kurang paham terhadap penjelasan guru, anak dapat mencari pembelajaran tersebut di youtube. Youtube juga di gunakan sebagai hiburan bagi anak-anak maupun orang dewasa. Pada zaman sekarang anak sangatlah mudah untuk menggunakan media sosial hingga anak usia dini sudah mahir dalam menggunakan gadget.

Selain aplikasi TikTok dan youtube terdapat game online seperti misalnya PUBG, Freefire dimana penyebarannya sangat luas dan dimainkan oleh anak usia dini juga. Game yang dimainkan menggunakan internet dan menggunakan teknologi yang ada. Game online biasanya dimainkan bersama teman yang berada didekat kita atupun yang jauh dari kita. Game online di mainkan ketika kita merasa penat ataupun stress, ataupun memang anak tersebut sudah hobi dalam bermain game online. Mengapa game online banyak digemari 
oleh banyak orang, karena game online lebih seru di bandingkan game offline. Karena game online mempunyai banyak konsep, dari model game nya, level game nya, dan lain sebagainya. Game online juga menyediakan banyak jenis game dari jenis game yang sederhana sampai game yang luar biasa. Karena teknologi jaman sekarang sudah sangat canggih. Jadi mau permainan apa saja pasti ada di game online. Bermain dengan game online ini dengan duduk manis saja kita bisa bermain game seseru mungkin. Game online tidak semua berbayar, karena ada game online yang gratis yang dapat di nikmati oleh para anak-anak.

Jika kecanduan game online, anak akan memiliki pengaruh yang buruk dan anak tidak tertarik lagi dengan kegiatan lainnya, dan melupakan waktu akademik dan melupakan kesehatannya serta menurunnya prestasi akademik anak. Game online juga mengakibatkan menurunnya daya tahan tubuh yang di karenakan kurangnya aktifitas, adapun gangguan mental anak tersebut, anak akan mudah marah, emosional. Anak usia remaja yang memiliki peran siswa ketika ia kecanduan game online kemungkinan akademik nya kan menurun, karena waktu luang yang ia miliki digunakan untuk memainkan game online bukan untuk belajar. Game online juga membutuhkan biaya untuk membeli paket internet agar dapat memainkan game tersebut jika game tersebut berbayar. Dan uang yang dibutuhkannya pun tidak sedikit. Pada saat ini banyak sekali anakanak yang sering nongkrong dengan temannya malam-malam sampai begadang hanya untuk main game online saja. Untuk itu kita sebagai orang tua jika mengenalkan media teknologi sejak dini pada anak kita harus membatasinya agar mereka tidak terlalu bergantung pada teknologi (gadget). Orang tua yang mengenalkan teknologi kepada anak sejak dini itu sangat bagus karena agar anak tidak ketinggalan jaman. Jika ada tugas yang menurutnya sulit dan belum mendapatkan jawaban, jika anak dapat menggunakan gadget mempermudah dalam mengerjakan tugas tersebut, jika anak belum mengenal gadget dan cara pemakaiannya pasti anak kesulitan. Tetapi harus kita ketahui jika mengenalkan gadget kepada anak harus dibatasi dan diawasi sampai benar-benar paham akan benar buruknya teknologi.

Game online tidak selamanya berakibat buruk. Game online juga dapat meningkatkan aktivitas otak anak, karena bermain game online perlu memerlukan konsentrasi yang kuat dan fokus agar dapat memenangkan permainan yang dimainkan, dan meningkatkan 
kecerdasan kognitif dalam membuat atau memecahkan masalah.membiasakan diri untuk melakukan aktivitas lebih dari satu karena memainkan game online melakukan kegiatan lebih dari satu dengan bersamaan. Game online juga dapat menghibur diri dengan cara yang berbeda, anak akan merasa lebih terhibur ketika sudah bermain game online, karena menurutnya game online yang menghilanggkan rasa lelah,penat, maupun stress. Biasanya game online dimainkan oleh anak yang usianya sekitar dari 4 tahun keatas. Game online tidak termasuk buruk jika penggunaannya sesuai atau tidak berlebihan.

\section{KESIMPULAN}

Perkembangan teknologi pada zaman sekarang berkembang sangat pesat sehingga masyarakat tergantung dengan teknologi. Teknologi dizaman sekarang sangat canggih dan berkembang sangat pesat. Teknologi merupakan sarana atau metode yang menyediakan sesuatu yang diperlukan oleh manusia sebagai kenyamanan dan kelangsungan hidup. Teknologi akan membuat perubahan, kemajuan, dan peningkatan. Modernisasi merupakan transformasi dari keadaan masyarakat yang sederhana kearah yang lebih baik atau masyarakat yang lebih maju. Teknologi zaman sekarang sudah sangat canggih, dari yang bisa buat sms dan telephone, teknologi sekarang sudah memberikan kemudahan bagi masyarakat. Karena teknologi saat ini terdapat yang namanya internet. jika kita ingin mengetahui informasi apapun dapat dicari lewat internet, butuh apa aja kita dapat mencarinya diinternet. Karena internet terdapat informasi-informasi terkini dari dalam negeri maupun luar negeri. Apabila ingin mencari ilmu pengetahuan pun ada di internet.

Pengaruh media sosial bagi anak akan membuat anak lebih mementingkan gadgetnya dari pada keluarganya. Bahkan ia lupa akan waktu, lupa akan belajar dan lainnya. Dan menjadikan anak malas untuk berfikir. Apabila anak kecanduan gadget akan mengakibatkan dampak yang buruk dalam aspek kesehatan, aspek akademik, keuangan, dan lainnya. Gunakanlah teknologi seperlunya dan sebaik mungkin. 


\section{DAFTAR PUSTAKA}

Adhipurna, L. G. (n.d.). Ulasan Kritis terhadap Model-model Kecerdasan Berbasis Neuroscience: IQ, EQ, dan SQ | Wong Solo. Retrieved September 29 , 2020, from https://supraptojielwongsolo.wordpress.com/2008/05/24/ulas an-kritis-terhadap-model-model-kecerdasan-berbasisneuroscience-iq-eq-dan-sq/

Ariantoro, T. R. (2016). Dampak Game Online Terhadap Prestasi Belajar Pelajar. JUTIM, 1(1). Retrieved from http://jurnal.univbinainsan.ac.id/index.php/jutim/article/view/ 22

Chusna, P. A. (2017). Pengaruh Media Gadget Pada Perkembangan Karakter Anak. Dinamika Penelitian: Media Komunikasi Sosial Keagamaan, 17. Retrieved from http://ejournal.iaintulungagung.ac.id/index.php/dinamika/article/view/842

Johann, V. E., \& Karbach, J. (2018). Validation of new online gamebased executive function tasks for children. Journal of Experimental Child Psychology, 176, 150-161. https://doi.org/10.1016/j.jecp.2018.07.009

Junida, D. S. (2019). kecanduan Online Anak Usia Dini. WALASUJI, 10(1), 57-68. Retrieved from https://www.neliti.com/publications/292832/kecanduanonline-anak-usia-dini

Machali, I. (2014). Dimensi Kecerdasan Majemuk Dalam Kurikulum 2013. Insania, 19(1). Retrieved from http://ejournal.iainpurwokerto.ac.id/index.php/insania/article/ view/462

R Elindawati. (2020). DAMPAK GAME ONLINE BAGI PENDIDIKAN ANAK. Journal IAIN Ternate. Retrieved from http://journal.iainternate.ac.id/index.php/alwardah/article/view/217

Rohman, K. (2018). Agresifitas Anak Kecanduan Game Online. Martabat: Jurnal Perempuan Dan Anak, 2(1). Retrieved from http://ejournal.iain-

tulungagung.ac.id/index.php/martabat/article/view/1435

Safira, A., \& Ifadah, A. (2020). Pembelajaran Sains dan Matematika Anak Usia Dini. Retrieved from https://books.google.com/books?hl=en\&lr=\&id=w9_8DwAAQBA $\mathrm{J} \& \mathrm{oi}=\mathrm{fnd} \& \mathrm{pg}=\mathrm{PA} 28 \& \mathrm{dq}=\mathrm{Lucky}+\mathrm{G}+\mathrm{A} .+$ Ulasan+kritis+terhadap+ 
model-

model+kecerdasan+berbasis+neouroscience:+IQEQ,dan+SQ.+Jo urnal+of+Psyche+2002\%3B1:1-

16\&ots=Rw0v5bVb0g\&sig=pS63kUs2ls6MVnALBOjGL3GhIJA

Strauss, V., \& Gardner, H. (2013). Howard Gardner: "Multiple intelligences" are not "learning styles" at 4:00 am. courses.educ.ubc.ca (Vol. 16). Retrieved from www.multipleintelligencesoasis.org

Suarca, K., Soetjiningsih, S., \& Ardjana, I. E. (2016). Kecerdasan Majemuk pada Anak. Sari Pediatri, 7(2), 85. https://doi.org/10.14238/sp7.2.2005.85-92

Susilowati. (2018). Pemanfaatan Aplikasi TikTok Sebagai Personal Branding Di Instagram (Studi Deskriptif Kualitatif Pada Akun @bowo_allpennliebe). Jurnal Komunikasi, 9(2), 176-185. https://doi.org/10.31294/jkom.v9i2.4319

Suhaimi, I. (2017). Memberdayakan Kecerdasan Kinestetik Anak Untuk Budaya Literasi Bahasa. Jurnal Kredo, 1(1), 72-90. Retrieved from

https://jurnal.umk.ac.id/index.php/kredo/article/view/1754

Viana, J. R. O. (2020). Pembelajaran Gerak Dan Lagu untuk Meningkatkan Kecerdasan Kinestetik Anak Usia Dini. 6(2), 108118.

Retrieved from https://www.mendeley.com/catalogue/df79d52e-cb95-34c9a8a4-

f32b7503c536/?utm_source=desktop\&utm_medium $=1.17$.11\&ut $\mathrm{m}_{-}$campaign $=$open_catalog\&userDocumentId $=\% 7 \mathrm{Be} 83 \mathrm{fad} 41$ 7736-33b4-8fb8-d003dd3a3c49\%7D 